Pakistan Journal of Humanities and Social Sciences

October - December 2018, Volume 6, No. 4, Pages 600-611

\title{
Public Investment in Social Sector in Pakistan: Trends and Issues
}

\author{
Sadia Idrees ${ }^{1}$ and Nor'Aznin Abu Bakar ${ }^{2}$ \\ ${ }^{1} \mathrm{PhD}$ Scholar, School of Economics, Finance and Banking (SEFB), College of Business \\ (COB), Universiti Utara Malaysia. \\ ${ }^{2}$ Associate Professor, School of Economics, Finance and Banking (SEFB), College of \\ Business (COB), Universiti Utara Malaysia. \\ Email: midrees485@gmail.com
}

\begin{abstract}
The purpose of this research article is to investigate the key issues, problems and the new challenges in education and health sectors of Pakistan. The functions of health and educational institutions are to develop the people physically, mentally, psychologically, socially and spiritually. It improves and promotes the economic, social, political and cultural life of the nation. In Pakistan, after more than five decades, the developmental indicators are not showing positive results. There are problems of quality of staff, students, library and laboratory, poor quality of Health Information Management System, lack of Governance. Relevance with society needs, research facilities, financial crisis, arts students more than science students weaknesses of examination, ineffective governance and academic results are not at par with international standards. Considering the gigantic problems of education and health sectors in Pakistan, the researcher selected this topic for research
\end{abstract}

Keywords: Public Investment, Health, Education, Pakistan

\section{Introduction}

On wider scale, the basic purpose for developing is the improvement of individual's livings and allowing them to attain their appropriate life goals (Rawls, 1971; Sen, 1999). Therefore, people should have accessibility to the things needed to accomplish these goals. Those things include economic resources, authorities, education and health. The spending on these sectors has a direct impact on health and educational development. That is the reason that development of social sector has always remained essential for all economic plans articulated by both the international support organizations and national-level policymakers (Economic Survey, 2016).

The education is a foundation stone in the process of economy development and accessibility of standard education is the fundamental right for the individuals who live in a 
country. It could perform a central part for the development and growth of the nation by productivity enhancement of labor and improving the capability of individuals to involve innovation in their activities and acquire the benefits from the advancement of technology (Bakar, Hasseb \& Azam, 2014). Furthermore, education also plays a persistent role in the improvement of other areas of social segment; like political structure, health and social setting (Ali \&Jabeen 2015).

Investment of educational institutions has improved per capita income of Grand National Product, lowered the poverty and increased the knowledge spreading in society (Chaudhry \& Rehman, 2009). Education has also played a substantial role to reduce the inequality of incomes in society (Danacica, Belascu\&Llie, 2010) along with reducing the rate of child labor, crimes and terrorism in the society by the reduction of poverty. The basic reasons of all these crimes are the poverty, hunger and not being able to meet the necessities of life (Kruger \&Malečková, 2003; Fabre \&Augersaud-Veron, 2004).

Along with education sector, health segment is also a significant division of the economy of any country. The healthy residents are not only respected for their personal rights, but they also increases human capital of a nation with positive contribution to the societal and economic progress. A healthy labor force automatically increases the overall production and in response lead to the economic development of country. "I'll being" and "ill health" is a multifaceted word which covers not only the concept of illness rather it covers other scopes like starvation, exclusion, inaccessibility, uncertainty and inability. Thus, the investment of any country in its health division put an ongoing influence on its success and prosperity (Pakistan economic survey, 2006-07).

Despite considerable economic development in Pakistan, the coverage and quality of service delivery in social sectors have remained inadequate because the extremely low level of public investment is the major cause of the poor performance of Pakistan's social sectors (health \& education). This is why the chief objective of current research is to explain the issues in the social sectors of Pakistan also these issues will based on annual year data of social indicators of health and education in Pakistan which will be collected from Pakistan Economic Survey (2016) and Annual Reports of State Bank of Pakistan (2016). Moreover, in present study the role of Public Investment in social sectors development of Pakistan will present in detail. 


\section{Social sectors Indicators (Trends and Issues in Pakistan)}

The concept of development is very much broad as it covers various areas, but it is very much related to the health and education sectors (Dreze\& Sen, 1989). The health, education and economic development are closely associated with each other which develops a foundation for the increase in income level, productivity growth, employment opportunity and technological advancement which finally enhance the quality of life (Pattayat\& Rani, 2017). The main purpose of this study is the investigation of vital matters for the social sector development in Pakistan including education and health divisions. From almost five eras, the indicators of development are not displaying a satisfactory picture in Pakistan.

For the economic growth and progress of any country, education and its role is no doubt a fundamental part (Benos\&Zotou, 2014; Raut, 2017; Van den Berg, 2016). It not only provides the improvement in the productivity but also make contribution to the economy by providing trained labor (Hanushek, Schwerdt, Woessmann, \& Zhang, 2017; Jung, 2015; McCullough, 2017). Rate of literacy of any country is the key indicator of education of that country. Unluckily, the track record of Pakistan's literacy rate has never been reasonable or even satisfactory. The literacy rate of people of 10 years and beyond is nearly $60 \%$ as compared to $58 \%$ in 2014 . The literacy rate of male population in the year 2015 was $70 \%$ and for the female population was $49 \%$ showing a gap of $21 \%$ of female literacy that must be filled by the availability of resources to balance the education of females and males (Pakistan Social and Living Standards Measurement (PSLM) Survey 2015).

\section{Figure 1: Education Indicators}

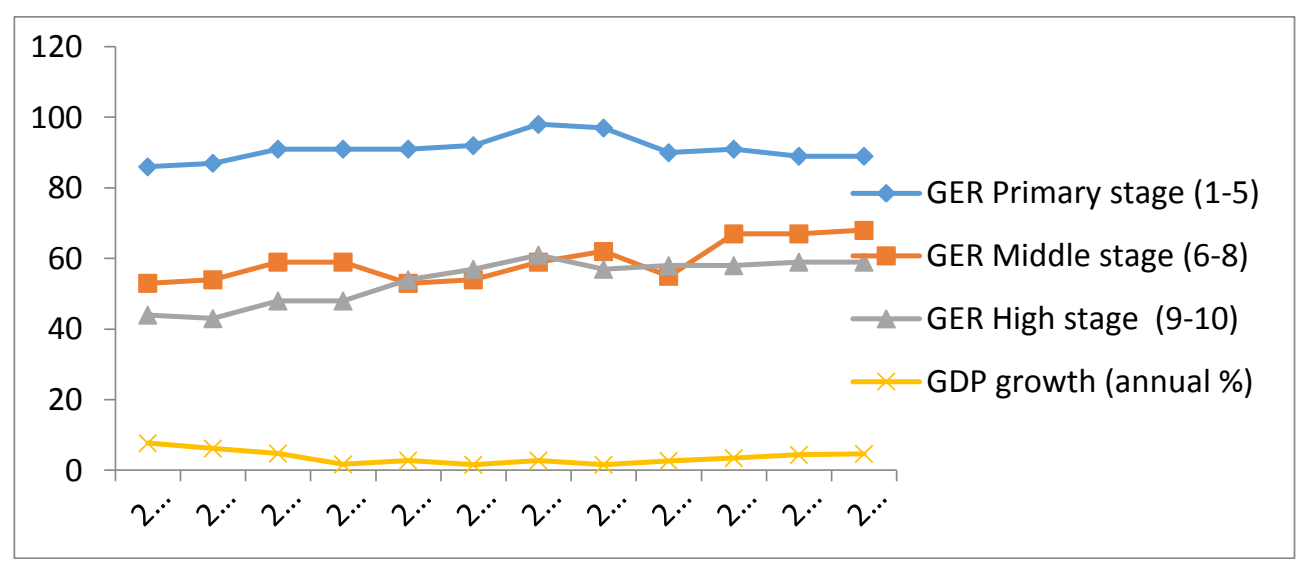

Source: Pakistan Economic Survey, 2016

Furthermore Gross Enrolment Rates (GER) is also an indicator which is discussed as the rate of participation of kids who attend the primary education institutes divided by figure 
of kids having age of 5 to 9 years. A higher Gross Enrolment Rate shows a greater participation level that the student is appropriate for the certified age group or not. Actually, status of education of Pakistan is far below in comparison with the further countries having same per capita income level. Likewise, by year end 2000, the primary class gross enrolment rate of SAARC countries was above $100 \%$ mark, but excluding Pakistan. And the recent gross primary enrolment rate is at $86 \%$ which is lower than $100 \%$ mark (Human Development in South Asia 2003, MHHDC).

A comparison of primary, middle and high school gross enrolment ratios (GER) in 2005 and in 2015-16 yields some interesting result. It is essential to progress in this area, as facts illustrate that GER scores drop drastically for all provinces when it comes to middle schools. One major reason for this is that $87 \%$ of the primary schools falls under public sector administration and only $13 \%$ are the private schools in the country. But the ratio of public to private gets revers for middle level schools, where 38\% come in public sector, while the widely held $62 \%$ fall under private domain. Graphical representation of education indicators facts of Pakistan clearly shows that education structure is not performing well. Finding out of the factors causing the problems to education sector development factors in the present situation is a crucial requirement. These issues involves faulty syllabi, double standard teaching, poor teachers' quality, cheating in exams and over-crowded classrooms. In spite of clear significance of Education sector for the development of country, this sector is ignored (Annual Report State Bank of Pakistan 2016).

The teachers' quality is not good in Pakistan, although teachers are vital for education sector. The reason behind it is low-level educations mandatory for becoming a school teacher of primary class; including 10 years of school education and then 11 month diploma program. This is proven from several studies that the achievement and success of learner is highly linked to amount of years of teacher's formal schooling. Another aspect is related to teacher certification program quality, which is suffering from shortage of effective master trainers, low importance of teaching experience and lack of appropriate monitoring set-up for teachers (Memon, 2007).

The management of teacher training is the responsibility of provinces in Pakistan. Though, the curriculum division is administered by the federal government but they must also be responsible for teacher training institutes. The primary school teachers of public sector are qualified through the distance education program of the Allama Iqbal Open University (AIOU), Government Colleges for Elementary Teachers, and the training courses for teacher 
run in secondary schools known as Normal Schools. These institutes teach a similar syllabus, and then the graduates get the Primary Teaching Certificate at the end of one year. In general, the amount of applicants is much greater than available number of seats. There is also severe deficiency of facilities of teacher training, mainly for female teachers in some specific regions and particularly Baluchistan province. Vocational training provision is the duty of Curriculum Boards and Extension Centers.

Education Extension Center is in each province which is responsible for in-service education. The main aim is to provide the training to every teacher atleast one time in the time span of five years. It was revealed in a recent study regarding the refresher courses in Punjab that the courses related to INSET did not reach at significant number of teachers. There are a number of teachers who have never received any in service training and they are at the end of their professional career.

As there is lack of planning for properly train the teachers and support mechanism for them in the private schools along with death of qualified teachers, the quality of education in such institute is a big question mark. Some private schools like Lahore Grammer, City Schools and Beacon House school system are the exception which are very small percentage of the present private schools. Whereas, majority of other schools have employed the faculty having the qualification upto 12 years of schooling (Intermediate) or 14 years of education (BA level). Additionally, such faculty members do not have any job security and are paid very less as compared to other people working in government sector.

There school systems and schools have developed training programs for teachers managed by their own. They also access the private institutions that are specialized in training. The preference of such school system is to hire the teachers who are fluent in English language. They do not prefer the faculty member who is already trained by the government and having the degrees like B.ED or M.Ed. So, there is very less percentage of the teachers hired by these private schools who are already trained. It is very important to enhance the professional skills of the teachers working in these private institutions.

In order to improve the quality of education Pakistan is taking a number of steps like encouragement of the private sector to produce quality education, improved facilities, qualified and well trained teachers, and strong curriculum. For this reason, the quality of education has increased $100 \%$ since last decade. It is an interesting fact that the cost of education is increasing 10 percent every year since April 2014 till June 2015 (Pakistan Education Statistics, 2016). On the other hand the per capita income is not rising at the same 
pace as the fee of the private school is increasing. This situation is creating problem for a number of families as the parents are unable to pay the school fee of their children leading them to pull out the children from these schools in some circumstances (Pakistan Education Statistics, 2016). One of the important asset of human being is the health. A lot of obstacles are created in the life of people if this asset is not developed properly because its absence leads to a emotional and physical weakness in human. Whereas, due to better economic development the nutrition is improving, sanitation is getting better, rate of infant motality is reducing thus the expectancy of the life is increasing (Rico \& Turubiates, 2005; Akram,Padda $\&$ Khan, 2006). In Pakistan the expectancy rate is very low. Around the globe Pakistan is on the sixt number having the Tuberculosis and one of the only three countries having polio. Mortality rate under the age of 5 and infants, presence of neonatal is very high in Pakistan due to respiratory Illness, diarrhea, and malnutrition. The health sector of Pakistan is not showing a very satisfied picture despite the improvement in health indicators of Pakistan (State Bank of Pakistan Annual Report, 2015).

\section{Figure 2: Health Indicators}

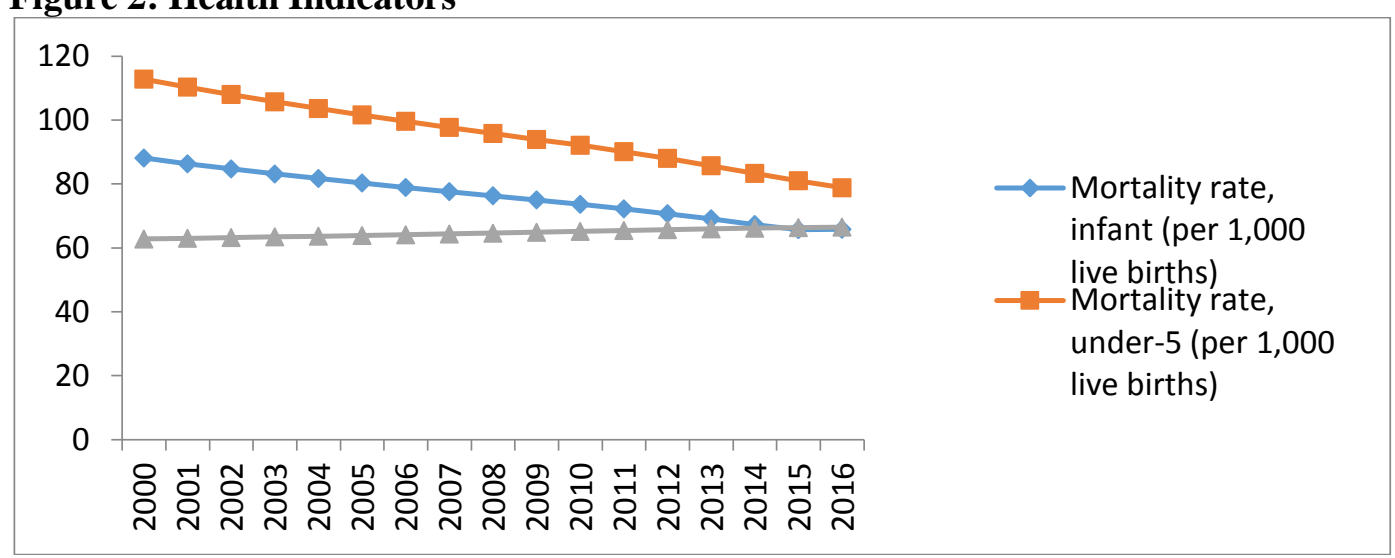

Source: Pakistan Economic Survey, 2016

There is positive impact of access to good health on social development and economy of the country. The infant mortality rate in Pakistan is almost 88.1 per thousand live births; 62 years only is the expectancy rate whereas the mortality rate under 5 years is 112.8 approximately in 2000 . The pace of improvement in the health sector is very slow despite the improvement in last few years (WDI, 2016). Pakistan is ranked after China, India, Indonesia, and Brazil as the sixth most populous country in globe having $2.5 \%$ population of the world.

The growth rate of population in Pakistan is continuously declining. In 1980 the rate was 3.6 percent whereas, it's been dropped to 1.8 percent in last three and half decade. 
Specially, the population growth rate was declined to 1.92 percent in the mid of 2004 from 2.1 percent in mid-2001. Previously, for the same period of time the fertility rate total fell (TFR) from 4.8 percent to 4.07 percent. It is important to focus on the TFR in order to slow down the growth rate of the population at the desired level. Whereas, in terms of reducing TFR in short period of time, Bangladesh is the role model. The experience of Bangladesh suggests that in order to be successful the focus must not be only on the one side like programs related to family planning. Integrated approach was adopted in Bangladesh due to which TFR fell rapidly in Bangladesh in which women empowerment and their education played a critical role (State Bank of Pakistan, annual report, 2015). The attempts to improve healthcare indicators over the past few years met with lower than expected success because of the direct increase in intensity of terrorist attacks on health teams; floods in many districts; and internal population displacement (Pakistan Millennium Development Goals 2016, Planning Commission of Pakistan).

\section{Figure 3: Health Indicators}

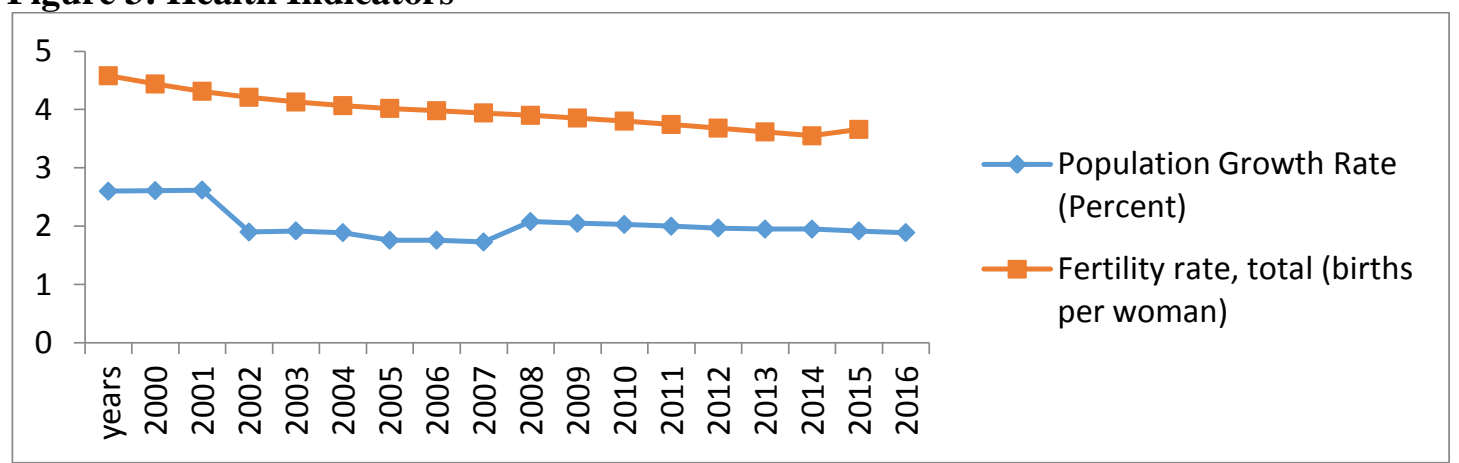

Source: Pakistan Economic Survey, 2016

The government is responsible for the provision of health care in Pakistan. There are 733 mother and child health centers and allied medical professionals, 675 rural health centers, 5464 basic health centers, 5695 dispensaries and 1167 hospitals under the public health system of Pakistan. The allied medical professionals include pharmacists, midwives, nurses and doctors. According to the figures of fiscal year 2016-17 there are 118869 beds in hospital, 16652 dentists and 184711 available in the country. The ratio of one dentist per 11513 person, one bed of hospital for 1613 person and one doctor for 1038 person. This figure clearly shows the shortage especially in the case of hospital beds and dentists (Pakistan Bureau of Statistics, 2016).

The role of private sector has increased too provide services due to the poor condition facilities of the public sector. Private healthcare providers are contacted by more than 70 
percent of the population of Pakistan whereas merely 20 percent rely on the services provided by the public sector. The low penetration of healthcare facilities in the public sector shows that around 61 percent of healthcare expenditures are done by the private funding which is also known as out of pocket expenditures. Additionally, private facilities mostly are available in urban areas due to which most of rural population cannot avail it (PSLM, Pakistan Bureau of Statistics 2015).

Pakistan is facing the most important problem which is geographical accessibility: 15 kilometer is the average distance of a village in Pakistan from a basic health unit (BHU) which is very high. Interestingly, the 12 percent of population of the rural areas of Pakistan has to travel around $26 \mathrm{KM}$ to reach BHU; in Baluchistan the 44 percent of population have no BHU around the distance of 26KM. Despite the fact that almost every infrastructure exists in the country, the availability of the professionals related to healthcare are not ensured especially the females. Moreover the absenteeism and weak monitoring also disrupt the delivery of services in thereareas. Additionally, the medicines and medical equipment's are not regularly available ((Pakistan Social and Living Standards Measurement Survey 2014$15)$.

Poor hygiene, lack of sanitation facilities and safe drinking water cause the sikn diseases, diarrheal diseases and acute respiratory infections. These are the leading cause of deaths in childhood in Pakistan. In the absence of disposal system of the solid waste in Pakistan and large amount of uncollected waste is causing a lot of damage to the health of public. 21 percent people living in Pakistan do not have the facility of toilet. In rural areas of Pakistan this problem rises to 31.5 percent. Moreover, more than 30 percent of the people use the toilet facility that is non-improved. On the other hand, only 50 percent of garbage is lifted from the urban areas and dumped at proper sites. Lahore and Karachi are the two cities which have the system of hospital waste. In terms of cleaning water only 20 percent of the people living in cities have the access of the piped water. Because of this reason most of the people use the hand pumps, boreholes or tube wells to access the water. Important thing is that only 1.5 percent of people living in rural areas and 20 percent of people living in uran areas use proper measures to clean the water they drink (Pakistan Demographic and Health Survey 2016).

The condition of women healthcare in Pakistan is very alarming. Moreover, the condition of women living in rural areas is even worst. As women are dependent on men financially and the restriction on mobility due to cultural factor, so they have less access to 
the health care facilities. Despite the existence of the demand, there is shortage of the access of the female healthcare facilities. For example, there must be a proper doctor who can look after the female during delivery and pregnancy to reduce the risk of morbidity. This care is denied to a number of women as there lack of female gynecologists in the health center (Pakistan National Report, 2016). Less than fifty percent deliveries between 2009 to 2013 were assisted by the skilled midwife, nurse or doctor. In rural areas the situation is even worst, in rural areas the situation is even worst, where only 43 percent of the healthcare centers have the women medical officer, out of which 80 percent had only one woman ( as surveyed in 2012). In rural areas more than half of births are attended by relatives or birth attendants. The statistice related to civil hospitals and tehsil headquarters are even more surprising. 280 such hospitals were surveyed out of which only 74 had the gynecologist (Pakistan Demographic and Health Survey 2016).

Insufficient availability of the public services is the most important concern in the healthcare system of Pakistan, which cannot be substituted for the low income earners with the facilities of private hospitals as they are costly. Problems related to health are vulnerable as well because of poor hygiene practices and poor sanitation in Pakistan. The rural areas of Pakistan are facing even more challenging situation and there is need to build the public infrastructure.

\section{Public Investment and Social sectors development of Pakistan}

Schultz (1961) and Becker (1964) pointed out that health of population and education are very critical for the growth of economy. Governments invest on the social sector like expenditures on health account and education in order to increase the productivity of the individual (Becker, 1964). Past literature has also emphasized on the importance of education and population health in order to explain growth and difference of growth in different countries (Barro and Sala-i-Martin, 1995). For the long term growth of the country, education and public health are of key importance (Baldacci et al., 2004).

Government of Pakistan is spending very low on the social sectors. From 1947 to 1987 spending on total social sector which consist of education and health was approximately $2.5 \%$ of the GDP of the country as compared to the average of $4.5 \%$ another developing countries like 9 percent in Indonesia; whereas this rate rise in developed countries up to $15 \%$ (Ahmed, 2016). Throughout the history, the allocation of development budget is very low. Government is unable to invest the requisite amount on health and education according to the 
growth of the population and it is evident from the tabular data (Ministry of Education, Government of Pakistan).

Figure 4: Health Indicators

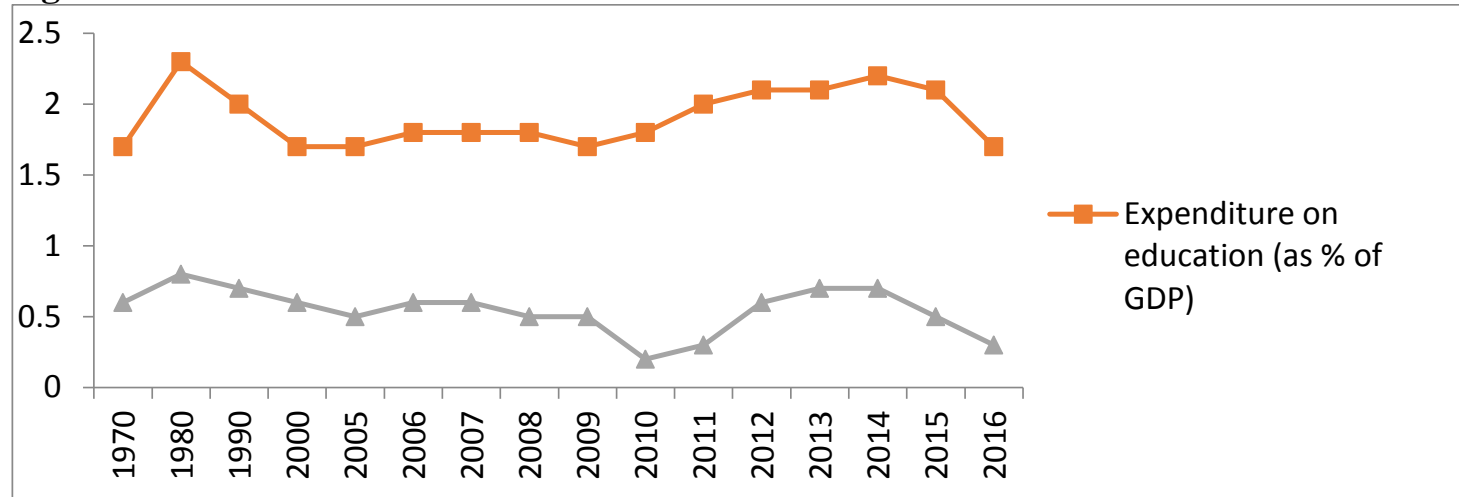

Source: Pakistan Economic Survey, 2016

Despite the fact that there is increase in expenditures on the public sector up to three times, spending of the government on the health sector remain very low and is continuously declining as the proportion of GDP. In the current fiscal year total expenditure on health for both provincial and federal government is expected to be 0.3 percent of the GDP, which is very low as compared to the recommendations of World Health Organization's recommendations of $5 \%$ (WHO, 2016)

\section{Conclusion}

The base of socio economic development is provided by health and education. The reason of the lack of growth of the poor countries is the poor quality of the education system. Present government in Pakistan has taken a number of steps to uplift the quality of education but still the quality of education is declining.in primary schools, the quality of teachers is questionable. Additionally, improvement in health sector of Pakistan is very slow since last fifty years which is also evident by the health indicators as well. On the basis of the above discussion it has been conclude that the social sectors (health $\&$ education) facing a worse situation in Pakistan. Most importantly, Pakistan's Government has been one of the low spenders on the social sectors. More than four decades after independence(1947), total social sector(health and education) spending was around 2.5 per cent of GDP compared to an average of 4.5 per cent in the developing countries (e.g. Indonesia 9 per cent) and 15 per cent in the developed countries. Government should take the steps to increase in health and education expenditures. In this regard earmarking, cut in the nonproductive expenditures, donor support, excise duties may be useful way to think about it. 


\section{References}

Abu, B. N., Haseeb, M., \& Azam, M. (2014). The nexus between education and economic growth in Malaysia: cointegration and Toda-Yamamoto causality approach. Актуальні проблеми економіки (12), 131-141.

Aguayo-Rico, A., Guerra-Turrubiates, I. A., Montes, R., Estudios, T., \& Monterrey, S. (2005). Empirical evidence of the impact of health on economic growth. Paper presented at the halshs-00678713, version 1-16 Mar 2012

Akram, N., Padda, I. u. H., \& Khan, M. (2008). The long term impact of health on economic growth in Pakistan. The Pakistan Development Review, 487-500.

Ali, H., \& Jabeen, A. (2015). Effects of Education on Economic Growth: Evidence from Pakistan. American Journal of Economics, Finance and Management, 1(6), 579-585.

Arora, S., 2001., Health, Human Productivity, and Long-Term Economic Growth, The Journal of Economic History.

Barro, R. (1995). Y SALAI-MARTIN, X. Economic growth.

Barro, R. J. (1991). Economic growth in a cross section of countries. The quarterly journal of economics, 106(2), 407-443.

Barro, R. J., \& Lee, J.-W. (1993). International comparisons of educational attainment. Journal of monetary economics, 32(3), 363-394.

Becker, G. (1964). human capital, NY. GS Becker.

Benos, N., \& Zotou, S. (2014). Education and economic growth: A meta-regression analysis. World Development, 64, 669-689.

Chaudhry, I. S., \& Rahman, S. (2009). The impact of gender inequality in education on rural poverty in Pakistan: An empirical analysis. European Journal of Economics, Finance and Administrative Sciences, 15(1), 174-188.

Dănăcică, D.-E., Belașcu, L., \& Ilie, L. (2010). The interactive causality between higher education and economic growth in Romania. International Review of Business Research Papers, 6(4), 491-500.

Dreze, J., \& Sen, A. (1989). Hunger and public action: Oxford University Press on Demand.

Fabre, A., \& Augeraud-Véron, E. (2004). Education, poverty and child labour. Paper presented at the Econometric Society 2004 Far Eastern Meetings.

Hanushek, E. A., Schwerdt, G., Woessmann, L., \& Zhang, L. (2017). General education, vocational education, and labor-market outcomes over the lifecycle. Journal of Human Resources, 52(1), 48-87.

HARYANA. Journal of Economics and Economic Education Research, 18(3).

Jung, D. B. (2015). Effectiveness of higher education to labor productivity. PEOPLE: International Journal of Social Sciences, 1(1).

Krueger, A. B., \& Malečková, J. (2003). Education, poverty and terrorism: Is there a causal connection? Journal of Economic perspectives, 17(4), 119-144.

Lucas Jr, R. E. (1988). On the mechanics of economic development. Journal of monetary economics, 22(1), 3-42.

Mankiw, N. G., Romer, D., \& Weil, D. N. (1992). A contribution to the empirics of economic growth. The quarterly journal of economics, 107(2), 407-437.

McCullough, E. B. (2017). Labor productivity and employment gaps in Sub-Saharan Africa. Food policy, 67, 133-152.

Memon, G. R. (2007). Education in Pakistan: The key issues, problems and the new challenges. Journal of Management and Social Sciences, 3(1), 47-55. 
Pattayat, S. S., \& Rani, P. (2017). SOCIAL SECTOR DEVELOPMENT AND ECONOMIC GROWTH IN HARYANA. Journal of Economics and Economic Education Research, 18(3).

PBS. (2016). Population Welfare Statistics Section. Retrieved 20 December, 2017, 2017, from http://www.pbs.gov.pk/content/population-welfare-statistics-section

Raut, L. K. (2017). Education and economic growth. Sustaining High Growth in India, 349.

Romer, D. (1986). A simple general equilibrium version of the Baumol-Tobin model. The quarterly journal of economics, 101(4), 663-685.

SBP. (2017). Annual Report 2016-2017 (State of the Economy). Retrieved from Pakistan: http://sbp.org.pk/reports/annual/arFY17/Chapter-01.pdf(Aguayo-Rico, GuerraTurrubiates, Montes, Estudios, \& Monterrey, 2005; Barro \& Lee, 1993; Mankiw, Romer, \& Weil, 1992)

Schultz, T. W. (1961). Investment in human capital. The American economic review, 51(1), 117.

Sen, A. (1999). On ethics and economics. OUP Catalogue.

Van den Berg, H. (2016). Economic growth and development: World Scientific Publishing Company. 